\title{
Mitigating Climate Change Effects on Hydrology through Participatory Sub-Catchment Management Planning: Case of Bwathonaro, Meru County, Kenya
}

\author{
Chris A. Shisanya ${ }^{1,2}$ \\ ${ }^{1}$ Department of Geography, Kenyatta University, Nairobi, Kenya \\ ${ }^{2}$ IMeRA-Institut d'Etudes Avancees de l'Universite d'Aix-Marseille, Marseille, France \\ Email: Shisanya.christopher@ku.ac.ke
}

How to cite this paper: Shisanya, C.A. (2022) Mitigating Climate Change Effects on Hydrology through Participatory SubCatchment Management Planning: Case of Bwathonaro, Meru County, Kenya. Open Access Library Journal, 9: e8372. https://doi.org/10.4236/oalib.1108372

Received: January 13, 2022

Accepted: February 25, 2022

Published: February 28, 2022

Copyright $\odot 2022$ by author(s) and Open Access Library Inc.

This work is licensed under the Creative Commons Attribution International License (CC BY 4.0).

http://creativecommons.org/licenses/by/4.0/

\section{(c) (i) Open Access}

\begin{abstract}
Management of water resources is very critical in the attainment of sustainable development goals (SDGs), in particular, Goal 6 (clean water and sanitation). Within the Kenyan context, a sub-catchment management plan (SCMP), is crucial as a planning tool involving management, use, development, conservation, protection and control of water resources at the local level. As such, its formulation and implementation is very important for the operationalization of Kenya Water Act 2016. Using field data, and participatory research appraisal (PRA) methodologies, the objective of this paper is to demonstrate using the case study of Bwathonaro how SCMP can be used to address the effects of climate change on hydrology at the local level. The paper recommends that local level institutions like the Water Resource Users Associations (WRUAs) should be supported by County Governments in Kenya to implement their respective SCMP, which would go a long way in addressing the local level sectoral effects of global climate change.
\end{abstract}

\section{Subject Areas}

Environmental Sciences

\section{Keywords}

Bwathonaro, Climate Change, Hydrology, Kenya, Sub-Catchment Management Planning

\section{Introduction}

Water is such an important resource for sustaining life on planet earth that it has 
a place among the Sustainable Development Goals (SDGs), in particular, Goal 6 (Clean Water and Sanitation) [1]. The current and projected trends in global water demand are likely to outstrip supply by over $40 \%$ by the year 2030 and in excess of $50 \%$ in developing countries, particularly in Sub-Saharan Africa (SSA) [2]. Given this scenario, estimates indicate that about 4 billion people globally experience extreme water scarcity at least one month in a year, while half a billion do so throughout the year [3]. It would thus appear that water scarcity situation in developing countries will remain precarious against the backdrop of current rapid population increase, urbanization and attendant economic development witnessed in these countries [4] [5].

Kenya's water scarcity has been a subject for discussion for a long time, given that a mere $11 \%$ of the land area can be classified as "high potential" in terms of agriculture while an overwhelming $89 \%$ falls under the arid and semi-arid lands (ASALs) [6]. Indeed, Kenya has elsewhere been classified as a chronically water-scarce country [7] [8] [9]. As a country, Kenya has only a mere 647 cubic meters per capita supply of annual fresh water [8]. Projections show that by the year 2025 the per capita renewable fresh water availability will drop to 235 $\mathrm{m}^{3}$.year ${ }^{-1}[10]$. At a global scale, a country falls under the category of "water-stressed" if the annual renewable freshwater supplies values are between 1000 and 1700 cubic meters per capita and "water-scarce" if its renewable freshwater supplies are less than 1000 cubic meters per capita [9] [11]. Only 8.3 percent of the countries in the world are classified as water-scarce, while 9.8 percent of the countries are considered water-stressed [11]. By comparison, Kenya's neighbors, Uganda and Tanzania have annual per capita renewable freshwater supplies of 2940 and 2696 cubic meters per capita per year, respectively [11].

In order to turn around the management of scarce water resources in the country, the Government in its wisdom has embraced decentralized oversight and control of water resources through the Integrated Water Resources Management (IWRM) framework whose pillars are anchored on the Dublin principles of participatory management of water resources [12] [13]. Key legal instruments that recognize the critical role played by community participation in decision making with regard to management of resources include the Water Act of 2002 [14], as well as the constitution of Kenya 2010 [15] and the recent 2016 Water Act [16]. These instruments paved way for the formation of Water Resources Users Associations (WRUAs) in six drainage areas of Kenya, namely: (Lake Victoria North Basin, Lake Victoria South Basin, Rift Valley Basin, Athi River Basin, Tana River Basin, Ewaso N'giro River Basin) (Figure 1). The 2002 legal instrument emphasizes the cardinal roles played by local communities in water resource management and makes an explicitly defined role for them in water resource management through Water Resource User Associations (WRUAs). In the [14] Act, these WRUAs are defined as community groups "focused on the management and conservation of water resources of a particular area, river or aquifer" ([14], section 15 (3) (e)). Further to the Act, WRUAs key objectives are to promote controlled and legal water use activities; good management practices 
that make efficient and sustainable use of water resources; the safeguarding of environmental flows for downstream ecological demands and basic human

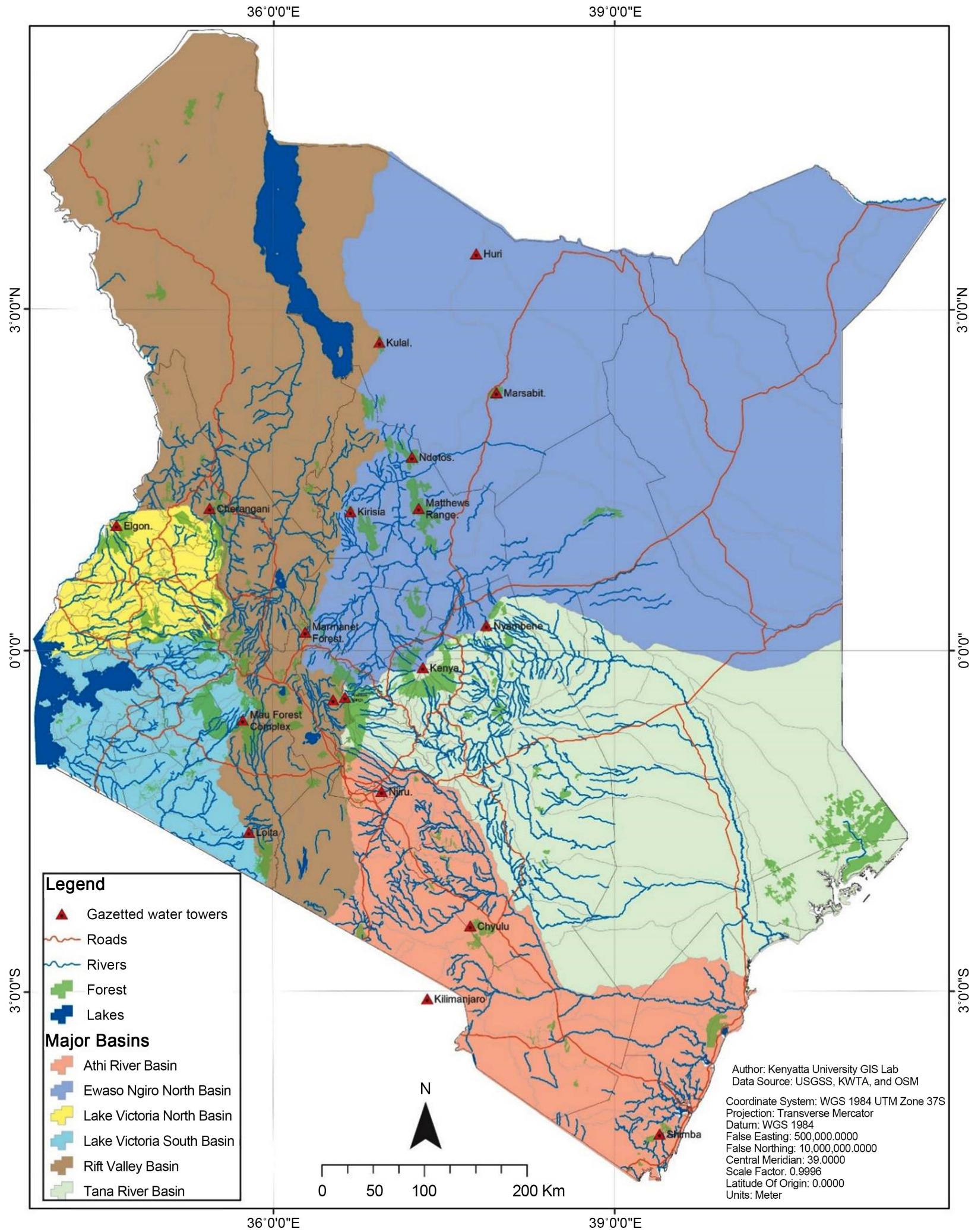

Figure 1. Kenya's six major river basin areas. 
needs; the reduction of water use conflicts; and catchment conservation measures to improve water quantity and quality.

According to Kenyan Law [16] management and use of water resources are regulated by the Water Resources Authority (WRA), and WRUAs are involved as grassroot managers. The following roles and responsibilities are outlined for WRA:

- Planning, management, protection, and conservation of water resources

- Allocation, apportionment, assessment, and monitoring of water resources

- Issuance of water permits

- Water rights and enforcement of permit conditions

- Regulation of conservation and abstraction structures

- Catchment and water quality management

- Regulation and control of water use

- Coordination of the IWRM Plan

On the other hand, the WRUAs play the following pivotal roles:

- Involvement in decision making process to identify and register water user

- Collaboration in water allocation and catchment management

- Assisting in water monitoring and information gathering

- Conflict resolution and co-operative management of water resources

For effective management of a sub-catchment, data is required on diverse biophysical, social and economic variables that are important ingredients in ensuring a holistic approach when examining the in-situ issues. The Sub-Catchment Management Plan (SCMP) evolved from water sector reforms, guided by strategies such as the national Water Resources Management Strategy (NWRMS) and the Catchment Management Strategies (CMSs). These are to be found in the legislative framework Water Act 2016 [16] and the Constitution of Kenya 2010 [15]. These national policies also consider the global agenda on environmental sustainability, as documented in Rio20+ [17] and Sustainable Development Goals (SDGs) [1]. Complimenting these global agenda are regional commitments, such as the Nile Basin Corporative Framework Agreement [18].

The aforementioned umbrella programmes can only be realized at grassroot level with the SCMP (Figure 2) being the epicenter of all activities. Thus, the SCMP evolution process is shepherded by the WRUA Development Cycle (WDC) document that describes all requisite processes and procedures that embrace capacity building and participatory involvement of all stakeholders. Against the above background, the overarching objective of this study is to demonstrate how SCMP tool has been used to identify existing challenges in a case study of Bwathonaro sub-catchment related to climate variability and change and their effects on hydrology at the grass root level in order to prioritize adaptation measures.

\section{Theoretical Framework Underpinning the Study}

From a theoretical view point, this study is informed by the cultural theory [19] [20] [21] as applied by [22], works of [23] [24] [25] [26] [27]. Given the 


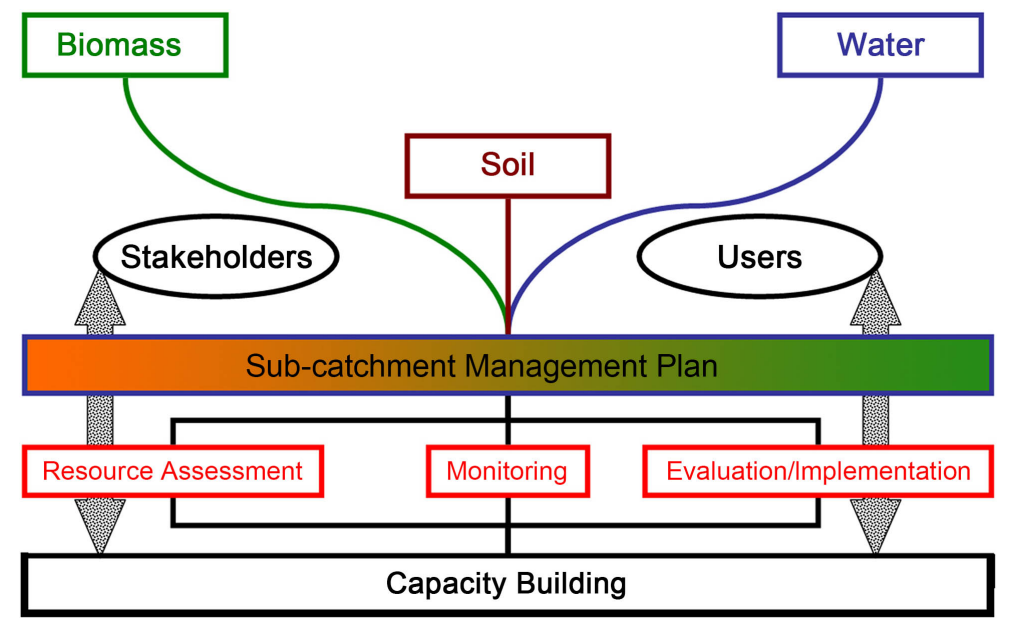

Figure 2. Developing a Sub-catchment management plan (Source: Author's conceptualization).

non-"excludability characteristic" ([28], p.198), river water qualifies as a common pool resource [23] [25] (Figure 3). In a seminal discourse, [27], critically evaluated the rules of engagement in contemporary common pool resource (CPR) user communities. Evidence from his evaluation showed that endogenous institutions were capable of managing CPR [29]. The principles associated with this management capability, which have also informed the water sector reforms in Kenya are listed in Table 1. According to ([29], p.640), “Ostrom's work has been pivotal in excavating and packaging up the knowledge to craft local natural resource institutions through commons projects". In the CPR theory, resource users undertake to design and use principles that are communally acceptable to make regulations whose objective is to create norms of compliance and cooperation in order to sustainably exploit the resource in question. Further, it is wished that CPR should be protected and nurtured so that their benefits can be continuously exploited. The theory recognizes that CPR can be over-exploited, polluted and destroyed unless concerted regulations defining limits for acceptable use are put in place and enforcement mechanisms operationalised.

Depending on the geographical location, water resources can potentially elicit conflict between upstream and downstream users [22]. It is therefore understandable for the downstream and upstream users to cultivate and nurture cooperation that emphasizes the importance of collective action over CPR management [28]. This view point of collectivity resonates well with one of the key tenets enshrined in the Kenya Water Act 2016 [16].

\section{Materials and Methods}

\subsection{Study Area}

The content of this sub-section is largely derived from the work of [30]. Geographically, the Bwathonaro catchment (Figure 4) is bounded by latitude $37^{\circ} 53^{\prime} 00^{\prime \prime} \mathrm{E}$ and $38^{\circ} 05^{\prime} 00^{\prime \prime} \mathrm{E}$ and $0^{\circ} 12^{\prime} 00^{\prime \prime} \mathrm{N}$ and $0^{\circ} 21^{\prime} 00^{\prime \prime} \mathrm{N}$ with the Nyambene 
Hills as its catchment [30]. The population is estimated at 46,000 people, who are mainly agriculturalists. The altitude ranges from $2060 \mathrm{~m}$ a.s.l. in Ngawa Hills to $700 \mathrm{~m}$ a.s.l. at the park area. The climatic conditions of the catchment range from humid to semi-arid. Rainfall is bimodal coming during the long rainy season of March to May and the short rainy season from October to December and varies from about $1300 \mathrm{~mm}$ at the hill tops to $600-700 \mathrm{~mm}$ in the plains around Amwathi. The months of January to February and August to October are dry and very challenging with the area experiencing decreased water availability.

High grid

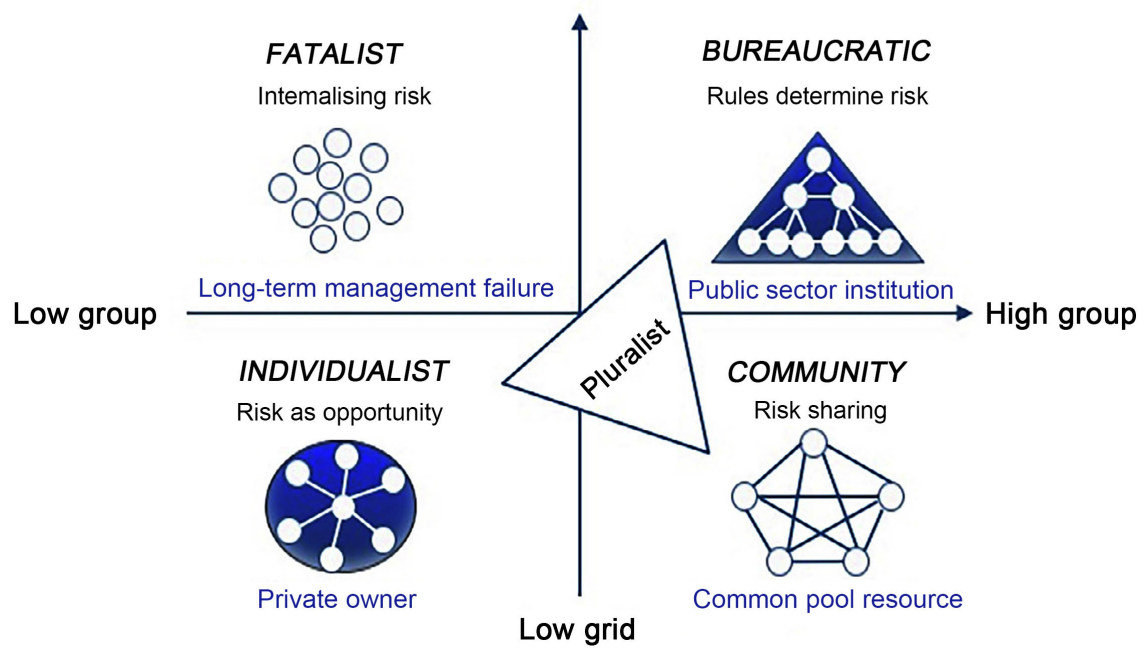

Figure 3. Institutional pluralism in managing water point risks (adapted from [23]).

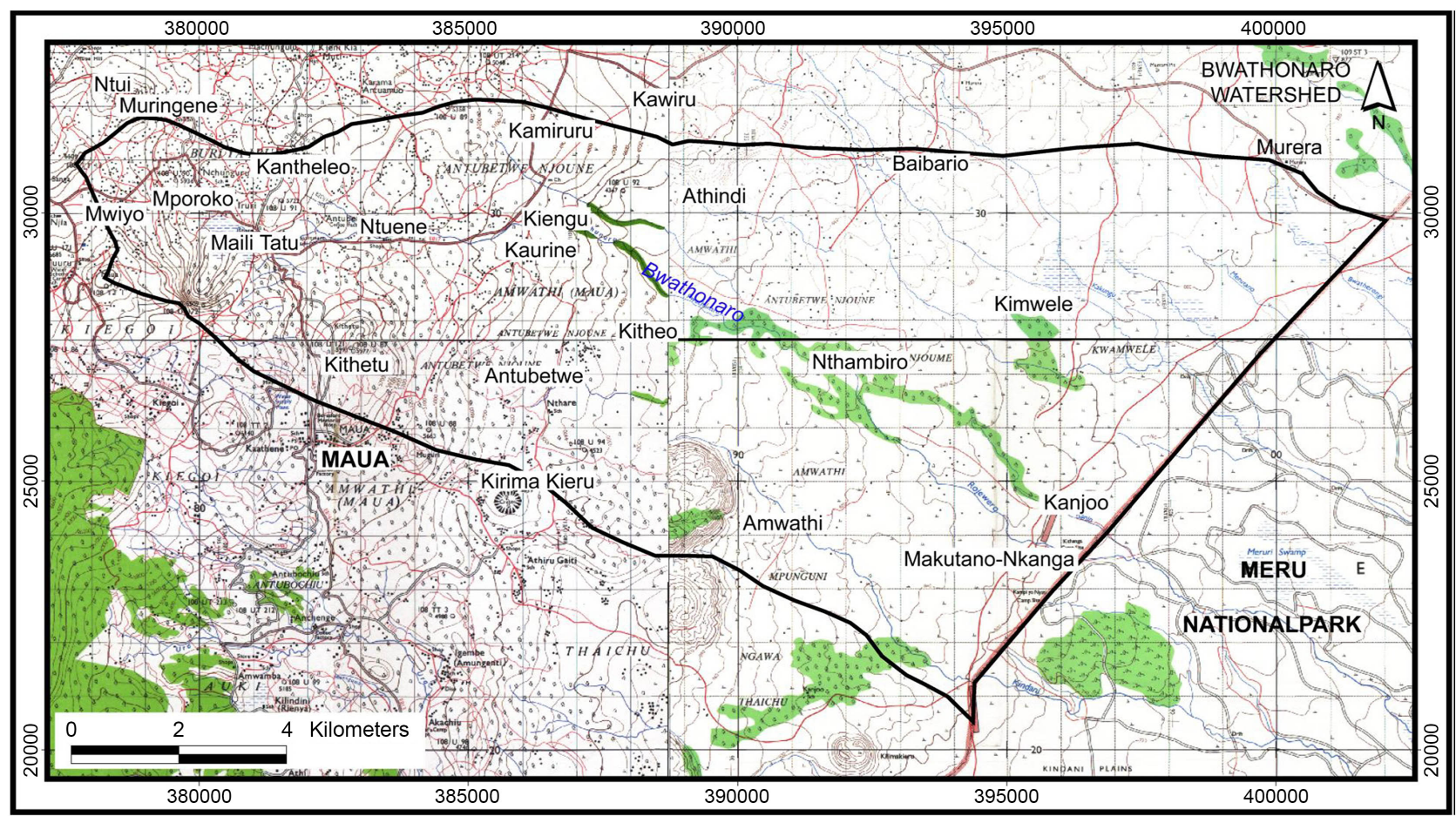

Figure 4. Map of Bwathonaro watershed (Source: [30]). 
Table 1. Ostrom's design principles of enduring commons institutions.

1) Clearly defined boundaries (membership and physical boundaries of resource are clear)

2) Congruence between appropriation and provision rules and local conditions (rules are congruent with local conditions)

3) Collective choice arrangements (individuals affected can participate in modifying operational rules)

4) Monitors are accountable to the resource users

5) Graduated sanctions against violators

6) Ready access to conflict-resolution mechanisms

7) Recognition of rights to organize, by external government authorities

8) Nested enterprises (where the resource is part of a larger system)

Source: ([27], p.90).

The geology of the catchment comprises mainly basaltic volcanic rocks with tuffs and pyroclastics of Pleistocene Age. They are young geologically and of clastic nature and have poorly developed soils. Because of climatic variation with altitude, variable soils have developed. The soils are poorly consolidated and with the combination of steep slopes are highly susceptible to erosion. The sources of the drainage into the Bwathonaro catchment contain the porous rock surfaces which allow water to percolate into the deeper horizons underground. Because of this fact irrigation activities lose water from the open furrow structures developed for that purpose. The ground water table is very deep.

Livestock rearing is another important activity in the catchment and includes the keeping of cattle, goat, sheep, donkey and chicken. Donkeys are also an important form of transport, particularly for firewood, water and other goods to the market within the catchment. Market centres such as Muringene, Nthambiro, Kiengu and Kanjoo have grown mainly through miraa trade. The main source of energy for cooking in the homesteads within the catchment is firewood. The demand for firewood has led to depletion of indigenous tree species, scarcity of wood resources, deforestation, high prices and introduction of eucalyptus species. Additionally, women are forced to walk longer distances to collect firewood.

\subsection{Research Methods}

This qualitative study focused on Bwathonaro watershed where the locals' perceptions about the environment and more importantly climate change effects on water were thought to be enriching. We sub-divided Bwathonaro river into three parts (Upper, Middle and Lower) and purposively selected 36 elderly villagers (both male and female) (12 villagers from each river part), who participated in focus group discussions (FGDs). In addition, one FGD was held with officials of the BWARUA. Thus, a total of 4 FGDs were conducted. The three FGDs in the river zones consisted of minimum of 9 and maximum of 12 male and female participants whose ages were between 60 to 75 years. Our focus was on FGD 
participants who had lived in the watershed for long periods of time and could give rich accounts about climate variability over time. These participants were selected through snowballing after engaging the Nyumba-kumi village heads, who would easily refer us to most appropriate respondents with rich mental knowledge of the watershed. The language used for discussions was Kiswahili, but where respondents preferred to converse in Kimeru (the predominant local language in Meru County), a member of the local community acted as an interpreter after prior training. The recruited interpreter was a fluent speaker of the local language and had firsthand knowledge of the area under study. We recorded all discussions with the respondents after seeking prior informed consent [31]. Discussions were translated from Kimeru into English during discussions and thereafter during transcription. The discussion topics covered the participants' perceptions of climate variability and change in Bwathonaro watershed, changes in Bwathonaro river flow over time, sharing of the water resources among communities staying in Bwathonaro watershed, challenges they face in conserving Bwathonaro river water. The venue for the FGDs was a central place in the river part, where water-related barazas are usually held. Each FGD session lasted for about 120 minutes. Guided field walks to observe certain water-related activities along Bwathonaro river were made by the entire group at the end of each FGD.

\subsection{Data Analysis}

Data analysis was conducted ex ante using Atlas-ti based content analysis [32] [33]. The analysis process began during the FGD sessions in order to confirm the accuracy of responses recorded and to deduce meanings of local beliefs and expressions about environmental phenomena. The responses were read to the participants at the end of discussion sessions to check their accuracy before they were translated into English. By espousing this method, the analysis was guided by the multiple evidence paradigm, according to which the study assumed that the views of the villagers about water resource and conservation practices could be used to enhance knowledge of climate change adaptation [34]. The themes emanating around discussion topics informed data analysis. Every effort was made during the analysis to draw a balance between local community indigenous knowledge and western science thinking [35].

\subsection{Ethical Considerations}

Ethics was an integral part of this study right from the planning stage to the actual implementation of the study. In order to carry out the research, the researcher first obtained an introduction letter from Kenyatta University The respondents were provided with adequate information about the aims of the study, the procedures to be followed, and the possible benefits for them and the manner in which the results would be used. Ethical clearance was sought from the Kenyatta University Ethics Review Committee. The ethical guidelines covered debriefing, voluntary participation, informed consent, beneficence, confidentiality and anonymity and the right to withdraw from participation. 


\section{Results and Discussion}

\subsection{Local Community Perception of Water Resource}

The respondents were requested to provide their perceptions on the topic of the importance of water resource. Their responses are presented in Table 2.

From Table 2, it can be seen that a common thread flowing through these responses is the strong spiritual connectedness between the community and water resource. In fact, it is not just the living but it transcends into the world after death, represented by the "ancestors". Thus, the community sees their role to protect water resource through what they perceive as its importance as amplified by the following statements in Table 2 "We worship our Gods at water source points", "We use water to wash the body of our dead before going to meet our ancestors in the next world". This intricate relationship between spirituality and human-nature relations has been documented in rural landscape of Zimbabwe [36] [37].

To further illustrate the importance of managing water resource among the Ameru, the following narration was presented in one of the group discussions during FGD in Upper Bwathonaro river:

"Long time ago, the management of all our water bodies and water catchments in our catchment was the responsibility of the whole community members, whereas water access and user rights were vested in the hands of community elders, who controlled accessibility and utilization of various water sources and water points. The Ameru elders allocated water points to different clans and for different uses. During rainy season, ground water was used for livestock and wells were used for domestic needs. However, during dry seasons, when many streams dried up and wells were operating at minimum, the elders raised an alarm for livestock to use dry season watering points, thus releasing the nearby wells for domestic use. This work that used to be carried out by our elders is now being done by the $B W A R U A$, through our SCMP' (FGD, Upper Bwathonaro River).

Table 2. Perceptions of water resource by the Local Community in Bwathonaro Watershed.

1) Water is life; but it can also be death!

2) A gift from God to sustain humankind

3) Water supports everything on earth

4) We use water to purify ourselves spiritually

5) We use water for our religious ceremonies

6) Water is the only commodity we share equally in the community

7) Water brings about enduring peace

8) Water does not have a "bad heart"

9) We use water to wash the body of the dead before going to meet our ancestors in the next world

10) We use water in many of our cultural rights of passage

11) We worship our Gods at water point sources 
Indeed, water as a resource has a strong traction to both physical and spiritual well-being of humankind. As ([38], p.1) observe, "Regardless of differences in religion, culture, and social norms, every person depends on water". Several researchers note that Paganism, Christianity, Buddhism, Islam, and many other religions, all have strong connections with water as a spiritual realm or a means of cleanliness before their Gods [39] [40]. Religious teachings and traditional institutions have a direct or indirect influence on ways of water management [38]. Most religions have been exercising the concept of the dominion of man over natural resources. Even though religious or social institutions are all for protecting natural resources and sharing them equitably, well intentioned efforts have not yielded positive results given that water resources are continuously overexploited and polluted, without putting any premium on sustainability for future generations [39].

\subsection{Challenges Facing Bwathonaro River Catchment}

Bwathonaro river catchment is experiencing severe water related challenges due to high population pressure and over-reliance on water for livelihood (irrigation). Nyambene Hills, which is the source of the Bwathonaro River, provides 7\% of the flow of the Tana River. Bwathonaro River supports irrigated agriculture, which is a major source of livelihood for people in the watershed. The reserve flows of the river are important for watering wild animals in the Meru National Park and for feeding the Tana River further downstream.

During the FGDs, participants were unanimous on the challenges facing Bwathonaro river catchment in order of ranking as follows (FGDs, Upper, Middle and Lower Bwathonaro river):

1) Climate variability and change that is affecting the regular supply of water

2) Water pollution from washing, bathing and watering of animals directly in the river

3) Pollution of water from point sources (abattoirs, toilets, market centres etc.)

4) Inappropriate solid waste disposal in market centres

5) Illegal water abstraction and over-abstraction of water

6) Inefficient irrigation practices

7) Encroachment on and drainage of wetlands/Inappropriate use of agro-chemicals in wetlands

8) Introduction of eucalyptus species

9) Soil erosion on the farms, footpaths and roadsides

10) Lack of water resource information (water quantity, quality, rainfall, water use, sediment yield)

11) Human and wildlife conflicts

12) Dependence on a single external source of water

The above list of challenges resonates very well with the findings of ([41], p.332) that: 
"Climate variability and change, changing land use systems and practices as well as in a rapidly growing human population, especially in the footzones and adjacent lowlands have exerted unremitting pressure on water resources, especially because the demand for water by different user groups has continued to grow, against the backdrop of expensive alternative sources (rainwater and groundwater harvesting) and increasingly dwindling river water resources. As each of the user groups moves to make substantial claims to available river water, competition for the resource becomes even sharper, thus setting the stage for conflicts related to scarcity that intensify during the dry season, at times resulting in fatal physical conflicts among different user groups in the basin, especially between upstream and downstream users".

\subsection{Specific Impacts of Climate Change on Bwathonaro River}

A key aspect for discussion during FGDs was the impact of climate change on water availability in Bwathonaro catchment and how the community is adapting. The following is a detailed assessment of the situation from the local community perspective:

"In the old days, when we were young, population in this catchment was sparse. But in recent decades, human populations have soared, livestock numbers have increased too, even as pasture shrinks due to human settlement and changes in land use. As a result, there simply isn't enough water for everyone. Underground water, the last recourse for downstream communities, is a finite resource requiring heavy capital investment beyond the means of most of us who need water the most-especially during dry seasons when water, or lack thereof, becomes a matter of life and death! For us here in Bwathonaro global warming and climate change are real life changing and threatening phenomena. Here, like in most parts of dryland Kenya, droughts are now more recurrent, severe and prolonged. Longer droughts destroy pasture and dry up water points, forcing illegal abstraction of water upstream, which leads to conflicts in the catchment among farmers and between humans and wildlife. Meanwhile, upstream farmers pump too much water from the drying blue lifelines for irrigation, worsening an already dire situation downstream. But we thank God that we have $B W A R U A$ that has tried its very best to minimize these conflicts by putting in place rules and regulations to govern water use in the catchment" (FGDs, Lower Bwathonaro River)

Climate change is becoming one of the most serious challenges to Kenya's achievement of its sustainable development goals as described under Vision 2030. Over the past few decades Kenya has experienced severe droughts. Kenya is already extremely susceptible to climate-related events, and projections indicate that the impacts are likely to affect the country even more in the future. In many areas (our study area included), extreme events and variability of weather are now the norm: rainfall is irregular and unpredictable; some regions experience frequent droughts during the long rainy season [42]. The droughts have 
affected water resources in Kenya and this was experienced and declared national disasters in the years January 1997, December 2000, March to June 2004 and December 2005 [43]. This indicates that in the last decade alone there have been four cases of major climate-related crises all as a result of drought. This is as a result of climate change and has posed a challenge by reducing the amount of water resources that are already scarce [44].

\subsection{Water Allocation in Bwathonaro}

Respondents were asked to respond to the question of how they allocate Bwathonaro water resource. Their response in the Upper Middle and Lower zones confirmed the views they presented to BWARUA for implementation in their SCMP. Thus, the following has been agreed upon:

"We advised BWARUA that during the months of August, September, and January, only 1 sprinkler per user is allowed along the river and secondary supply pipes are operational on alternate days. During the dry months of February and March, no irrigation is allowed during the day, water is reserved for domestic use and livestock only. We are very happy that this is being followed to the letter. At least we have no complaints of users not getting adequate water" (FGDs, Upper, Middle and Lower Bwathonaro river)

Water allocation is a water management planning tool that ensures equity in access and use of water resource. According to [45], water allocation plans should achieve the following objectives as opined also during focus group discussions:

- Equity: the fair use and prioritization of water between different user groups and geographical regions.

- Environmental protection: recognizing the importance of different water-dependent ecosystems and providing adequate water to maintain important processes.

- Development priorities: supporting and promoting economic and social development at the regional and national scale, including protecting existing uses.

- Balancing supply and demand: Structuring the supply of water so that it does not exceed the demand within the natural variability of the system, preventing water shortages.

- Efficient use of water: promoting water users to utilize the most efficient use of freshwater resources.

\subsection{Intervention to Address Major Causes of Water Conflicts Related to Climate Change}

In this era of climate variability and change, equitable abstraction, distribution and use of water resource in Bwathonaro catchment brings to the fore associated complex determinants of water management aspects that could have far reaching ramifications. As [46] point out that the more water becomes scarce, the 
more we have water-related tensions at different scales. These tensions, coupled with a number of socioeconomic, political, environmental and cultural factors determine the probability of a water-related conflict to trigger off. The above was captured aptly during the FGDs as follows:

"One of the most significant contributions of the BWARUA in the prevention and resolution of water conflicts is through direct intervention to deal with the major causes of conflict, such as over-abstraction of water, illegal water abstraction, wasteful means of conveyance and irrigation, and delayed issuance of water permits. Those guilty of such offenses are compelled by the respective Association to take the necessary corrective measures; otherwise, they are reported to the relevant authorities for appropriate legal action. The WUAs have acted as pressure groups to press for speedy issuance of water permits by the concerned authorities." (FGD, Lower Bwathonaro river)

The spirit and letter of the intentions of BWARUA in addressing water related conflicts in Bwathonaro sub-catchment, include but are not limited to (FGD, BWARUA Committee Members):

- Promoting legal water abstraction and efficient and proper use of the abstracted water from Bwathonaro River and tributaries.

- Promoting sustainable water use, water management and water development of Bwathonaro River.

- Encouraging water conservation practices to ensure sufficient river flow to meet the demands of the environment, domestic and wildlife.

- Conserving the water quality of the Bwathonaro River.

- Providing a forum to discuss, prevent and resolve water use conflict.

- Promoting dialogue between water users and the government in regard to Water Act in respect of activities related to Bwathonaro River.

- Promoting a situation in which all modifications of existing river abstraction and all new river water abstractions must be recommended by the association before being considered by the relevant Government Water Board.

- Developing sustainable association, which is responsible for the management of the Bwathonaro River, through transparent and fair management practices.

\subsection{Dialoging and Arbitration of Potential and Existing Water Conflicts}

Practices (and developments) within the sub-catchment that have the potential to cause user conflicts are identified by the Water Situation Monitors and reported to the Executive Committee (members of the Association affected can also report directly to the Executive Committee), who move quickly to address the problem, either directly with the concerned party or parties or through the District Water Office. In other instances, the Executive Committee convenes a stakeholders' consultative meeting to deliberate over the problem and negotiate a win-win solution. Thus, most problems never get to the authorities because a workable resolution is negotiated and agreed upon at the user level. New water 
users are required to consult the Association through the Executive Committee, who commissions an overview assessment of the water situation to determine the implications of proposed new users. If it is determined that new uses will cause undesirable effects that could lead to conflicts, a general meeting is convened to discuss the best ways of allocating water to new applicants, using existing water abstraction points without affecting the river flow downstream. Even where water permits from the Water Office exist, actual abstractions are subject to discussions and negotiations among the other members of the Association in order to ensure that implementation of permit provisions does not lead to any shortages that could cause conflicts. Furthermore, some well-established WUAs have drawn up area-based Water Abstraction Schedules to guide water abstraction among different user groups. This has become a very effective and popular tool for regulating abstractions and ensuring flows of water downstream most of the time. The success of these negotiations underscores the need for multi-stakeholder meetings in the effort to resolve conflicts over resource use.

\subsection{Beyond River Water Conflicts}

A critical problem BWARUA is now resolving at the moment is the ubiquitous occurrence of exotic tree species, particularly Eucalyptus, in the sub-catchment. Concerns over the negative effects of Eucalyptus on stream and catchment water yields are well documented [47]. It is against this background that BWARUA has embarked on an ambitious initiative to eradicate exotic trees from its catchments. During the FGD, a BWARUA Committee member had this to say about this initiative:

"It is better for us to know only one cause of our water shortages-that is climate change, rather than entertaining another cause-Eucalyptus, which we have brought in our farms by ourselves! At least for climate change, God can help us fight its impacts on our streams, but for Eucalyptus, we must fight this war and win it by ourselves. The only way out is to cut all these Eucalyptus trees from our catchment and instead plant indigenous tree species that use less water and have many more benefits to the community, like provision of traditional medicines." (FGD, BWARUA Committee Member).

Further to ensuring that water in the sub-catchment is guaranteed, despite the negative compounding effects of climate variability and change, BWARUA has embarked on securing wetlands that had been encroached within the sub-catchment. These efforts include fencing them off and acquiring title deeds of ownership.

\subsection{Challenges Ahead}

Despite the gains achieved by BWARUA in Bwathonaro Catchment, there are several challenges worth mentioning. First, there is a real danger of deviating from the primary objective of water-related conflict prevention and resolution as the Association tries to venture into other activities related to water management. It is for this reason that there is thinking to establish a WRUA Service Agreement (WSA)-A proposed performance based contract between the 
WRUAs and the Water Resource Authority (WRA). The agreement provides financial compensation for the functions performed by the WRUA, and thus gives the WRUA the financial resources to carry out their duties. WSA clarifies and structures the relationship between WRA and the WRUAs in terms of regulation and management of water resources. The WRUA becomes the true eyes and ears of the WRA and the action arm of county governments' riparian responsibilities. It helps the WRA through the regular monitoring of river flows, data collection on legal and illegal abstraction, and it helps the county government in monitoring and managing the degradation of riparian areas and water pollution. This Agreement provides the incentive and means for WRUAs to take up their roles with responsibility and accountability-a WIN-WIN for water, catchments, and citizens of Kenya. Second, as the Water User Associations (WUAs) grow in number, they must face the challenge of how to ensure horizontal linkages and coordination so that they can learn important lessons and share experiences with best practices as a basis for improving their operations. Third, certain legal and institutional aspects remain unclear, especially regarding institutional positioning of the WUAs vis-à-vis the institutions responsible for water resources management, particularly at the County level. Finally, some of the facilitating (major) water users appear to have a hidden agenda in relation to the WUAs: WUAs can be misused as convenient platforms for public relations by large-scale commercial horticulturalists eager to continue using river water without interference from other smallholder agropastoralists in the neighborhood of the study area and elsewhere. There is thus a need to begin addressing these issues before they affect the continued functioning of the WUAs, whose benefits so far cannot be overemphasized.

\subsection{Implications for Climate Change Adaptation}

Given the strong spiritual beliefs that underpin water conservation in Bwathonaro catchment, the participants had a myriad of perceptions related to the climate change construct and attendant water scarcity. The commonality in perceptions is that "climate change is caused by failure of humanity to conserve forests in our watersheds that trap moisture that trickles down to feed our rivers and streams". They further emphasized this point as follows:

"When individuals in the society fail to respect our local customs (protection of the environment) as passed unto us by our forefathers and ancestors, you make them very annoyed in their graves and their wrath manifests itself through the many environmental challenges we are currently witnessing, for example, erratic rainfall, drought, water scarcity. This is a punishment from our ancestors!" (FGD, BWARUA Committee).

It is evident from the above observations that the following are key drivers that are likely to influence climate change interventions in the long run in Bwathonaro catchment, and more importantly, water resources, through the lenses of a traditional setting: 
- Local communitys' knowledge that climate change is real.

- Their understanding that destructive human activities negatively affect the availability of water resources.

- Their collective ownership of water resources gives them legitimacy to jealously guard it against any internal or external misuse.

The above resonates well with ([48], p.1) that "beliefs and values of indigenous peoples can provide important insights into human relationships with nature. Indigenous world views can offer alternative solutions to restoring degraded ecosystems and suggest new frameworks for building a more sustainable, holistic and equitable approach to the management of natural resources".

\section{Conclusions}

Through the BWARUA SCMP interventions, there is a strong probability of efficiently managing the water resources within Bwathonaro sub-catchment under the threat of climate change. The way forward for the sustainable management of water resources by BWARUA can be realized through:

- Capacity building of BWARUA in all issues relating to integrated watershed management.

- Awareness creation among communities to change attitudes towards ownership and management of water resources.

- Sustainability of BWARUA as an entity.

- Exposure of BWARUA through exchange visits to see what other communities are doing in water resources management.

- Establishment of demonstration sites for best practices.

- Harmony and synchronization of activities among WRMA, BWARUA and other stakeholders.

- Monitoring of sub-catchment dynamics.

- Involving young environmentalists like the school pupils.

- Data collection and management within the sub-catchment.

It is evident that integrated watershed management is being embraced as a viable means of sustainable water resources management in Kenya. In the face of climate change, the BWARUA through its SCMP has initiated various water resources management strategies highlighted in this paper that are responding to climate variability and change. There is however need to consolidate these local level initiatives by up-scaling capacity building efforts of BWARUA and awareness creation on emerging water governance approaches. Perhaps more important is the fact that effective and efficient community participation in water resources management through SCMP offers a clear opportunity in sustainable natural resources management in Kenya under a changing climate.

\section{Acknowledgements}

I am grateful to the participants from Bwathonaro river catchment, who willingly and generously shared their knowledge about their water resources and spent 
their much valued time with us during the field work. In particular, I am indebted to the support given by the Nyumba Kumi elders who helped us identify the desired respondents from each river zone. We also acknowledge the invaluable support given by the BWARUA Committee members who assisted in identifying the most appropriate participants and helped in organizing focus group discussions. The invaluable input of the local research assistants in field trekking and transcribing and translating field notes is much appreciated.

\section{Conflicts of Interest}

The author declares no conflicts of interest.

\section{References}

[1] United Nations (UN) General Assembly (2015) Transforming Our World: The 2030 Agenda for Sustainable Development. https://www.refworld.org/docid/57b6e3e44.html

[2] Chellaney, B. (2013) Water, Peace, and War: Confronting the Global Water Crisis. Rowman \& Littlefield Publishers, Lanham. https://rowman.com/ISBN/9781442221390/Water-Peace-and-War-Confronting-the Global-Water-Crisis

[3] Bakker, K. (2012) Water Security: Research Challenges and Opportunities. Science, 337, 914-915. https://doi.org/10.1126/science.1226337

[4] Ondigo, D.A., Kavoo, A.M. and Kebwaro, J. (2018) Water Resources and Management Under Increasing Urban Demography: A Kenyan Perspective-A Review. Journal of Water Resource and Protection, 10, 919-938. https://doi.org/10.4236/jwarp.2018.109054

[5] Engel, K., Jokiel, D., Kraljevic, A., Geiger, M. and Smith, K. (2011) Big Cities, Big Water, Big Challenges: Water in an Urbanizing World. World Wildlife Fund, Koberich.

[6] Government of Kenya (GoK) (2018) Ministry of Devolution and ASALs. State Department for Development of the Arid and Semi-Arid Lands: Strategic Plan (2018-2022). Government Printer, Nairobi.

[7] Mulwa, F., Li, Z. and Fangninou, F.F. (2021) Water Scarcity in Kenya: Current Status, Challenges and Future Solutions. Open Access Library Journal, 8, e7096.

[8] Mogaka, H., Gichere, S., Davis, R. and Hirji, R. (2006) Climate Variability and Water Resources Degradation in Kenya: Improving Water Resources Development and Management. World Bank Working Paper No. 69. The World Bank, Washington DC. https://doi.org/10.1596/978-0-8213-6517-5

[9] World Bank (2000) World Development Report 2000/2001: Attacking Poverty.

[10] Government of Kenya (GoK) (2006) Ministry of Water and Irrigation. The National Water Resource Management Strategy (2006-2008). Government Printer, Nairobi.

[11] Jones, J.A.A. (2014) Water Sustainability: A Global Perspective. Routledge, Abingdon-on-Thames.

[12] Richards, N. and Syallow, D. (2018) Water Resources Users Associations in the Mara Basin, Kenya: Pitfalls and Opportunities for Community Based Natural Resources Management. Frontiers in Environmental Science, 6, Article No. 138. https://doi.org/10.3389/fenvs.2018.00138 
[13] Manzungu, E. and Derman, B. (2016) Surges and Ebbs: National Politics and International Influence in the Formulation and Implementation of IWRM in Zimbabwe. Water Alternatives, 9, 493-512.

[14] Government of Kenya (GoK) (2002) The Water Act 2002 (Cap 372). Government Printer, Nairobi.

[15] Government of Kenya (GoK) (2010) The Constitution of Kenya. Government Printer, Nairobi.

[16] Government of Kenya (GoK) (2016) Water Act 2016. https://wasreb.go.ke/downloads/Water Act 2016.pdf

[17] United Nations (UN) (2012) United Nations Conference on Sustainable Development, Rio de Janeiro, Brazil, 20-22 June 2012.

[18] Agreement on the Nile River Basin Cooperative Framework (2010). http://internationalwaterlaw.org/documents/regionaldocs/Nile River Basin Coope rative Framework 2010.pdf

[19] Douglas, M. (1994) Risk and Blame: Essays in Cultural Theory. Routledge, London.

[20] Thompson, M., Ellis, R. and Wildavsky, A. (1990) Cultural Theory. Westview Press, Boulder, CO.

[21] Wildavsky, A. (1987) Choosing Preferences by Constructing Institutions: A Cultural Theory of Preference Formation. American Political Science Review, 81, 3-21. https://doi.org/10.2307/1960776

[22] Koehler, J., Thompson, P., Goodall, S., Katuva, J. and Hope, R. (2021) Institutional Pluralism and Water Use Behavior in Rural Africa. World Development, 140, Article ID: 105231. https://doi.org/10.1016/j.worlddev.2020.105231

[23] Koehler, J. (2018). Exploring Policy Perceptions and Responsibility of Devolved Decision-Making for Water Service Delivery in Kenya's 47 County Governments. Geoforum, 92, 68-80. https://doi.org/10.1016/j.geoforum.2018.02.018

[24] Ostrom, E., Burger, J., Field, C.B., Norgaard, R.B. and Policansky, D. (1999) Revisiting the Commons: Local Lessons, Global Challenges. Science, 284, 278-282. https://doi.org/10.1126/science.284.5412.278

[25] Ostrom, E. and Gardner, R. (1993) Coping with Asymmetries in the Commons: Self-Governing Irrigation Systems Can Work. Journal of Economic Perspectives, 7, 93-112. https://doi.org/10.1257/jep.7.4.93

[26] Ostrom, E. (1998) A Behavioral Approach to the Rational Choice Theory of Collective Action: Presidential Address, American Political Science Association, 1997. American Political Science Review, 92, 1-22. https://doi.org/10.2307/2585925

[27] Ostrom, E. (1990) Governing the Commons: The Evolution of Institutions for Collective Action. Cambridge University Press, New York. https://doi.org/10.1017/CBO9780511807763

[28] Komakech, H.C. and van der Zaag, P. (2011) Understanding the Emergence and Functioning of River Committees in a Catchment of the Pangani Basin, Tanzania. Water Alternatives, 4, 197-222.

[29] Saunders, F.P. (2014) The Promise of Common Pool Resource Theory and the Reality of Commons Projects. International Journal of the Commons, 8, 636-656.

[30] Shisanya, C.A., Onywere, S.M. and Obando, J.A. (2017) Sustainable Water Resources Management for Food Security in Kenya: Case of Bwathonaro Catchment. Open Access Library Journal, 4, e3524.

[31] Bordens, K.S. and Abbott, B.B. (2008) Research Design and Methods: A Process 
Approach. 7th Edition, McGraw-Hill Companies, New York.

[32] Ogalleh, S.A., Vogl, C.R., Eitzinger, J. and Hauser, M. (2012) Local Perceptions and Responses to Climate Change and Variability: The Case of Laikipia District, Kenya. Sustainability, 4, 3302-3325.

[33] Muhr, T. and Friese, S. (2004) ATLAS.ti, the Knowledge Workbench: User's Guide and Reference. 2nd Edition, Scientific Software Development, Berlin.

[34] Reyes-García, V., Fernández-Llamazares, A., Guèze, M., Garcés, A., Mallo, M., Vila-Gómez, M. and Vilaseca, M. (2016) Local Indicators of Climate Change: The Potential Contribution of Local Knowledge to Climate Research. WIREs Climate Change, 7, 109-124. https://doi.org/10.1002/wcc.374

[35] Creswell, J.W. (2013) Qualitative Enquiry and Research Design: Choosing among Five Approaches. 3rd Edition, SAGE Publications, Thousand Oaks, CA.

[36] Chanza, N. and Musakwa, W. (2021) “Trees Are Our Relatives": Local Perceptions on Forestry Resources and Implications for Climate Change Mitigation. Sustainability, 13, Article No. 5885. https://doi.org/10.3390/su13115885

[37] Byers, B. (2004) Spirit Lions and Sacred Forests. In: Gottlieb, S., Ed., This Sacred Earth: Religion, Nature, Environment, Routledge, New York, 20-32.

[38] Behailu, B.M., Pietila, P.E. and Katko, T.S. (2016) Indigenous Practices of Water Management for Sustainable Services: Case of Borana and Konso, Ethiopia. SAGE Open, 6, 1-11.

[39] Chuvieco, E. (2012) Religious Approaches to Water Management and Environmental Conservation. Water Policy, 14, 9-20. https://doi.org/10.2166/wp.2011.000

[40] De Chatel, F. (2009) Bathing in Divine Waters: Water and Purity in Judaism and Islam. In: Oestigaard, T.T., Ed., A History of Water Series II: Vol 1. Ideas of Water from Ancient Societies to the Modern World, I.B. Tauris, London, 273-279. https://doi.org/10.5040/9780755620517.ch-011

[41] Bonface, K. and Gikonyo, J. (2002) Preventing and Resolving Water Use Conflicts in the Mount Kenya Highland-Lowland System through Water Users' Associations. Mountain Research and Development, 22, 332-337. https://bioone.org/terms-of-use

[42] Government of Kenya (GoK) (2013) County Integrated Development Plan Meru County. Government Printer, Nairobi.

[43] Government of Kenya (GoK) (2014) Agricultural Sector Development Support Program. Government of Kenya, Ministry of Agriculture Livestock and Fisheries.

[44] MoAlF (2016) Climate Risk Profile for Meru. Kenya County Climate Risk Profile Series. The International Center for TropicalAgriculture (CIAT) and the Kenya Ministry of Agriculture, Livestock and Fisheries (MoALF), Nairobi.

[45] Speed, R., Li, Y.Y., Le Quesne, T., Pegram, G. and Zhou, Z.W. (2013) Basin Water Allocation Planning: Principles, Procedures and Approaches for Basins Allocation Planning. UNESCO, Paris. https://www.adb.org/sites/default/files/publication/30247/basin-water-allocation-pl anning.pdf

[46] Maingey, Y., Opondo, M., Olago, D. and Ouma, G. (2021) The Impacts of Increasing Water Scarcity and the Potential for Water-Related Conflict in Lamu, Kenya. Water Supply, 2021, Article ID: ws2021299. https://doi.org/10.2166/ws.2021.299

[47] Albaugh, J.M., Dye, P.J. and King, J.S. (2013) Eucalyptus and Water Use in South Africa. International Journal of Forestry Research, 2013, Article ID: 852540. https://doi.org/10.1155/2013/852540 
[48] Parsons, M. and Fisher, K. (2020) Indigenous Peoples and Transformations in Freshwater Governance and Management. Current Opinion in Environmental Sustainability, 44, 124-139. https://doi.org/10.1016/j.cosust.2020.03.006 